\title{
The New Ethical Dimension of Sports Events: a Reflection on the Evolution from the Ancient Greek Olympic Sports Festival to Postmodern Sports Events
}

\author{
La nueva dimensión ética de los eventos deportivos: una reflexión sobre la evolución \\ desde la antigua fiesta deportiva olímpica griega a los eventos deportivos postmodernos
}

\section{Barbara Maussier}

Corso di Laurea in Scienze Motorie, Facoltà di Medicina e Chirurgia. Università degli Studi di Roma "Tor Vergata". Italia.

CORRESPONDENCIA:
Barbara Maussier
Recepción: enero 2015 • Aceptación: junio $2016 \quad$ bmaussi@hotmail.com

\begin{abstract}
The purpose of this paper is to identify the new social functions of sports events in postindustrial society starting from a reflection on the intersections in the relationship among the ethical values of the ancient Greek Olympic sports festival and the postmodern model of sustainable event management. From a literature review on leisure, sports, and event studies, it emerges that sports events, conceived of as postmodern festivals, can help people who take part in them experience a new ethical dimension and celebrate the spirit of ancient Olympia and its values in an innovative way. In summary, from the review of the above-mentioned literature emerges a set of ethical potentials of ancient sports festivals within the possible implementation of their intrinsic values in the context of contemporary sports events through the specific actions of planning and management for sustainable and ethical development.
\end{abstract}

Key words: Sports events, ethics, leisure, postindustrial, sustainable development, serious tourism.

\section{Resumen}

El propósito de este trabajo es identificar las nuevas funciones sociales de los eventos deportivos en la sociedad postindustrial a partir de una reflexión sobre las intersecciones en la relación entre los valores éticos de la antigua fiesta olímpica deportiva griega y el modelo postmoderno de gestión de eventos sostenibles. A partir de una revisión de la literatura sobre los estudios de ocio, deporte y eventos, se desprende que los eventos deportivos, concebidos como fiestas postmodernas, pueden ayudar a las personas que toman parte en ellas a experimentar una nueva dimensión ética, y celebrar el espíritu de la antigua Olimpia y de sus valores en una forma innovadora. En resumen, a partir de la revisión de la literatura mencionada, se desprende un conjunto de potenciales éticos de los antiguos festivales deportivos dentro de una posible implementación de sus valores intrínsecos en el contexto de los eventos contemporáneos a través de acciones específicas de planificación y gestión hacia un desarrollo ético y sostenible.

Palabras clave: Eventos deportivos, ética, ocio, postindustrial, desarrollo sostenible, serious tourism. 


\section{Introduction}

In the recent developments of postindustrial society, leisure has acquired a new relevance in postmodern life, both in quantitative and qualitative terms (Bell, 1973). Postmodern relativism and the consequent collapse of old cultural institutions and socializing agents has left a creative space for leisure, determining its new social functions. Postmodern events are spreading around the world as a growing sector of the leisure industry, becoming gatherings for sharing experiences and communicating value systems and lifestyles. Sports events, through different forms of participation, are some of the most widespread practices of leisure and may be interpreted as the new socializing agents of postindustrial society. According to the literature, there are different studies on the economic dimension of these events (Crompton, 1999; Mules \&Faulkner, 1996), but very few on their ethical dimension, which is the main topic of this paper. The purpose of this paper, through a reflection on the meaning of ethics in ancient Greek sports games, is to draw a comparison between this ethics and the characteristics of postindustrial society, proposing a new model for event management focused on creating social benefits. This approach is inspired by the philosophy of sports education which emerged from ancient Greek sports festivals such as the Olympic Games (Isidori, 2012; Miller, 2004; Reid, 2006) and by recent studies on the evolution of leisure, sports, and event management (Bell, 1973; Chalip, 2006; De Masi, 2015; Dunning, Murphy, \& Williams, 1988; Elias, 1988; Gibson, 2005; Getz, 2011; Porro, 2007; Lafargue, 1971; Lombardo, 2000;Lyotard, 1981; Marx, 1964; Richards, De Brito, \& Wilks, 2013; Russell, 2012; Stebbins,1982, 1996; Touraine, 1970). It emerges that contemporary sports events, as a form of postmodern festivals, can develop a new ethical dimension, celebrating, in an innovative way, the values of ancient Olympic sports.

\section{Method}

Using the comparative historical method, we can reflect on how the principles of the ancient philosophical and educational Olympics can be found and renewed in current sports events.

The research was designed with the objective to reflect on the evolution of the following seven dimensions:

1. Leisure time

2. Sports

3. The concept of the festival

4. Event tourism and serious leisure

5. The new community and social dimensions of event management
Table 1. Dimensions Literature Review

\begin{tabular}{|c|c|}
\hline Dimensions & References \\
\hline 1. Leisure Time & $\begin{array}{l}\text { (Bauman, 2002) } \\
\text { (Bell, 1973) } \\
\text { (De Masi, 1985) } \\
\text { (Dumazedier, 1978) } \\
\text { (Lafargue, 1971) } \\
\text { (Lipovetsky, 1995) } \\
\text { (Lyotard, 1981) } \\
\text { (Marx, 1964) } \\
\text { (Russell, 2012) } \\
\text { (Stebbins, 1982, 1996) }\end{array}$ \\
\hline 2. Sports & $\begin{array}{l}\text { (Brohm, 1976) } \\
\text { (De Coubertin, 2000) } \\
\text { (Dunning, Murphy, \& Williams, 1988) } \\
\text { (Elias, 1988) } \\
\text { (Elling, De Knop, \& Knoppers, 2001) } \\
\text { (García-Ferrando, 2006) } \\
\text { (Guttmann, 1978) } \\
\text { (Huizinga, 1983) } \\
\text { (Isidori, 2012) } \\
\text { (Knop, 1988) } \\
\text { (Lombardo, 2000) } \\
\text { (Porro, 2007) } \\
\text { (Reid, 2006) } \\
\text { (Rowe,1999) } \\
\text { (Thompson, 1969) }\end{array}$ \\
\hline 3. The concept of the festival & $\begin{array}{l}\text { (Apolito, 1994) } \\
\text { (Cardini, 1983) } \\
\text { (Durkheim, 1963) } \\
\text { (Getz, 2008) } \\
\text { (Maussier, 2014) }\end{array}$ \\
\hline $\begin{array}{l}\text { 4. Event tourism and serious } \\
\text { leisure }\end{array}$ & $\begin{array}{l}\text { (Costa, 2008) } \\
\text { (Ejarque, 2003) } \\
\text { (Ferrari, 2002) } \\
\text { (Getz\& Mc Connell, 2011) } \\
\text { (McKercher, Mei \& Tse, 2006) } \\
\text { (Ryan, 2002) } \\
\text { (Stebbins, 1996) } \\
\text { (Urry, 2000) }\end{array}$ \\
\hline $\begin{array}{l}\text { 5. The new community and } \\
\text { social dimensions of event } \\
\text { management }\end{array}$ & $\begin{array}{l}\text { (Arcodia\& Whitford, 2008) } \\
\text { (Burbank, Andranovich, \& Heying, 2001) } \\
\text { (Chalip, 2006) } \\
\text { (Fredline, Raybould, Jago, \& Deery, 2005) } \\
\text { (Fyall \& Jago, 2009) } \\
\text { (García, 2001) } \\
\text { (Gursoy \& Kendall, 2006) } \\
\text { (Maffesoli, 2004) } \\
\text { (Maussier, 2014) } \\
\text { (Mckercher et al., 2006) } \\
\text { (Melnick, 1993) } \\
\text { (Richards \& Hall, 2000) } \\
\text { (Turner, 1982) }\end{array}$ \\
\hline 6. Sports tourism & $\begin{array}{l}\text { (Gammon \& Robinson, 2003) } \\
\text { (Gibson, 2005) } \\
\text { (Martelli, 2010) } \\
\text { (Pigeassou, 1997) } \\
\text { (Weed \& Bull, 2004) }\end{array}$ \\
\hline $\begin{array}{l}\text { 7. Strategic event planning for } \\
\text { sustainable tourism }\end{array}$ & $\begin{array}{l}\text { (Bramwell, 1977) } \\
\text { (De Angelis, 2005) } \\
\text { (Getz, 2002, 2003, 2004, 2008) } \\
\text { (Maussier, 2010) }\end{array}$ \\
\hline
\end{tabular}




\section{Sports tourism}

7. Strategic event planning for sustainable tourism

For each dimension, the main sport sciences and sociology databases were used (mainly, SPORTDiscus and SocINDEX) by looking up the specific key words mentioned in the above list (Table1). Through a literature review of the sources mentioned above, it emerges that contemporary sports events, as postmodern festivals, have new ethical potentialities that can help to renew the values of ancient Olympic sports.

\section{Main Findings and Discussion}

In the following, it is argued that contemporary sports events embody features of ancient Greek sports games. The model of ancient Olympic sports can provide us with an example of a philosophical and cultural methodology to put sports values into practice in the context of peace and mutual comprehension. This methodology originates from the educational philosophy that inspired the ancient Olympic Games. The ancient Olympics, as well as other major games of ancient Greece (the Isthmian Games, the Pythian Games, the Nemean Games, and the Panathenaic Games), were celebration events which, through their organization and the religious philosophy that inspired them, aimed to promote values such as peace and mutual understanding using games and competitions as a means to achieve this goal (Isidori, 2012). According to Reid (2006), this philosophical methodology consists of three main steps, each based on specific values that are embodied by sports:

1. Peace: The first step is to cut out a situation made of "space" and "time" to set aside conflicts. This step is intended to create a moment of friendship between the people who are possibly in conflict.

2. Equality: The second step is to treat people as equals within the rules of the game. In this step, the rules of equality and fair play are created.

3. Respect for Diversity: The third and last step is to tolerate and celebrate differences, showing that they are actually only apparent and not substantial.

In this model, the values of peace, equality, and respect for diversity were made explicit in the organization of the ancient sports games such as Olympic Games (Isidori, 2012; Miller, 2004; Reid, 2006). The innovative aspects of this paper consist of identifying the new social functions of sports events in postindustrial society starting from the model of ancient sports festivals in Greece, such as the Olympic Games. Reflecting upon this model and its potential, this paper sketches a possible scenario in which to implement the values of sports as a human practice and adapt them to the contemporary social context. The potential of sports as they emerge from the ethical model of ancient sports festivals (Peace, Hospitality, and Religiosity) suggest some specific actions to reflect upon and investigate.

These actions allow us to look at sports as an effective social means to:

- develop a new community dimension;

- increase the social capital of the communities of people who host the event;

- renew the concept of hospitality through sports tourism planning;

- act as a new cultural medium oriented towards serious leisure.

Table 2. Virtues of ancient and postmodern sports events

\begin{tabular}{ccc}
\hline & $\begin{array}{c}\text { Ancient Greek } \\
\text { sports events }\end{array}$ & Postmodern sports events \\
\hline 1 & Peace & Community dimension and social capital \\
2 & Hospitality & Sports tourism \\
3 & Religiosity & Serious leisure \\
\hline
\end{tabular}

The next section considers how these ancient values have evolved in contemporary sports events and how they should be interpreted by specific actions of sustainable event management.

\section{From peace to community dimension and social capital development}

In ancient Greece, the space and time of peace created by the organization of the sacred Olympic Games and the philosophy of peace that inspired them used the game and the festivity as a means of gathering people together with the purpose of establishing a sense of dialogue and solidarity, beginning with $\mathrm{mu}-$ tual understanding.

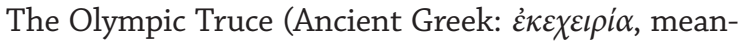
ing "the laying down of arms"), accepted and shared by the celebrant community through symbols, rituals, places, ceremonies, and languages, determined that sacred and liminal ${ }^{1}$ (Turner, 1969) space/time that pro-

\footnotetext{
1 In anthropology, liminality (from the Latin word lïmen, meaning "a threshold") is the quality of ambiguity or disorientation that occurs in the middle stage of rituals, when participants no longer hold their pre-ritual status but have not yet begun the transition to the status they will hold when the ritual is complete. According to Turner (1982) the liminal phase of the ritual creates two interrelated ways that form in one case a structure or antipodes an anti-structure, which is a communitas. The potential of the ritual extended to all cultural performances can operate creatively on some or all levels of society by creating change or it can serve as a reference model in the common thought of those who participate.
} 
vided the encounter and the celebration of the virtues of sports. According to Porro (2007), the evolution of the postindustrial society seems to have challenged the traditional values associated with sports by the Olympic Movement. Consider the debate on the spectacularization of sports events: on one hand is the positive impact on the growth of sports practitioners and the rising economic profits for all social actors involved in the triangle of sports, media, and sponsors (Aris, 1990); on the other hand, some have pointed out that the current consumer culture promotes only "dis-values," such as the pursuit of success, greed and an improved selfimage, and that there is a need to return to the "pure" values proposed by Olympism (Sugden \& Tomlinson, 2001; Tomlinson\& Young, 2006). The transformation of values in sports is part of a wider framework described by the transition to the postindustrial society called postmodernism (García-Ferrando, 2006). From the mid-twentieth century, the joint action of technological progress, organizational development, globalization, mass media, and mass education has produced a new type of society centered on the production of information, services, symbols, values, and aesthetics where time is a flow of experiences that provides for the simultaneous co-existence of work, play, and study (De Masi, 1985, 2002). In the postindustrial era (which began in America in 1956 when white-collar workers numerically surpassed blue collar workers for the first time, and the service sector exceeded the other sectors of the economy), thanks to technological and organizational innovation in the workplace, "time for oneself" has expanded. This is mainly a result of the deconstruction of space and time, determined by the advent of new information technologies and an organization of work that is more flexible and de-synchronized (Bell, 1973). According to the literature, the general increase of income levels, education levels and non-work time, are the socio-economic variables that have had a positive effect on the spread of cultural participation (Maussier, 2010). These variables have also contributed to the process of the democratization of sports, which were once considered an elite practice. It is sociologically interesting to reflect on the postmodern evolution of sports. According to Knop (1988), society was "sportivized" while sports were "desportivized". In other words, in the last decades of the past century, modern agonism (coded in rules, structured in institutions and even ritualized in symbols) has given way to new variations (Fitness and Wellness). Expanding the social citizenship of sports, the phenomenon of the "sportivization" of the society has fostered a diversity of subcultures and meanings attributed "to the agonism of modernity" with a new organizational model that moves sports from the traditional concept of measuring and comparing competitiveness. The concept of the "desportivization" of sports can attract a more extended demand of sports, customized and highly differentiated in time and space. In the postindustrial society, the de-synchronization of work and non-work activities has created a differentiation in the use of work time and leisure time (Lash \& Urry, 1994) that is no longer the same for everyone, but is fluid and adaptable in a very fragmented way (Bauman, 2002). In this new context, the concept of time and space (behind the concept of festivity) changes, and the impossibility of the holistic dimension of the festival becomes one of the reasons why many scholars, identified by Apolito (1994), believe that the festival has disappeared. These scholars do not recognize the characteristics of chorality and temporal totalization identified in the festivities of the past in contemporary forms of celebrations. Cardini (1983) affirms that the festival presupposes a community with organic language, and this type of community was, in the West, swept away by the industrial revolution and technological development, by the eclipse of the sacred and by alienation. Yet festivities will continue to be practiced, although in different forms, such as in the case of the many sports events which may have other extra-community objectives (such as tourism). The New York Marathon, like many other sports events of various kinds, expresses an anthropological need for festive collective rituality, not just a technical and competitive appointment (Elling et al., 2001; Lombardo, 2000; Heinemann \& Puig, 1996). It seems that for participants, participation in a cultural event can represent a moment to share collective rituals and be part of a community that communicates its own system of values. From this new context emerges a new dimension of community which is different from the postmodern individualism described by Lipovetsky (1995). Starting from a reflection on the overlapping nature and simultaneous coexistence of different moments of postmodern life (work time/leisure time), it can be assumed that a diversification in the perception of the "festival-event" emerges. Participation in an event will no longer be a prescriptive and codified experience, but will become a polysemic space within which individuals can assign their own meanings, recognizing themselves more or less in the new forms of postmodern sociability. Contemporary sports event participants can be interpreted as the new tribes described by Maffesoli (2004) that will be characterized by a communion of interests, lifestyles, and tastes that become new symbolic codes on which to rebuild the new community dimension of postmodern festivals (Maussier, 2014). Recently, many researchers have studied in depth how the community dimension 
can be planned and developed in event management, creating social capital (Arcodia \& Whitford,2008) and benefits for visitors and residential communities of people (Chalip, 2006). Despite the fact that the attention is usually focused on the economic impact of events (Crompton, 1999; Mules \& Faulkner, 1996), recently a number of researchers have devoted more attention to the social value that events can bring (Andersson, Rustad, \& Solberg, 2004; Burbank et al., 2001; Deccio \& Baloglu, 2002; Fredline \& Faulkner, 2001; Kim \& Uysal, 2003; Kim, Gursoy, \& Lee, 2006; Richards et al., 2013; Roche, 2000). According to Linda Wilks in her introduction to the recently-published book Exploring the Social Impacts of Events (Richards et al., 2013), social impacts ${ }^{2}$ could include the development of social networks, community pride, feelings of inclusion or exclusion, social integration, increased mutual understanding, changes in perceptions of attitudes, and the development or preservation of traditions. She affirms that it is important to consider and examine the many processes at work in the determination of these impacts at the individual level, as well as at the group and community level. According to Fredline, Jago, \& Deery (2003), unlike economic impacts, the social impacts of events can be difficult to measure objectively as many of them cannot be quantified, and they often have a differential effect on different members of the community. The relationship between the festival and increasing social capital (Arcodia \& Whitford, 2008) can be understood as the new community dimension of the postindustrial society. The concept of social capital (Portes, 1998) is used in the literature to indicate the ability of individuals to obtain benefits by virtue of their membership in social structures. The social capital developed by the festival is conceptualized not only as a resource in itself, but also as a vehicle for acquiring additional resources (Arcodia $\&$ Whitford, 2008). For McKercher et al. (2006), the festival can also become an excellent example of a sustainable tourism practice that benefits the host community. The concept of social impact assessment in general sustainability stresses the importance of a long-term approach and the integration of the interests of the community in decision making in order to develop local support for hosting such events (Fredline et al., 2005; Gursoy \& Kendall, 2006). The nature and quality of the

2 The few academic articles that refer specifically to the social impact of events appear in a variety of subject areas within the academic press, including in tourism journals (Hall \& Hodges, 1996), sports management journals and geography journals (De Bres \&Davis, 2001). The newly emerging event management academic press, including journals such as Event Management and the Journal of Policy Research in Tourism, Leisure and Events, is starting to provide a dedicated home for events-focused research with a social dimension (Delamere, Wankel, \& Hinch, 2001; Wilks, 2011). social impact of the event depends on the programming, which must aim to generate value (Bramwell, 1997; Burbank et al., 2001; Ritchie, 2000). The anthropology of events shows that their celebratory nature generates a liminoid space that is a potentially fruitful area for rewriting cultural codes for social transformation, which can promote social value, in particular through a sense of communitas (Turner, 1969, 1974, 1982). According to Chalip (2006), to activate and amplify the sense of liminality and communitas, event organizers and planners from the host community should encourage social interaction and the celebratory dimension, allowing moments of social interaction among visitors of the event, creating related social events, facilitating informal social opportunities, and producing themed events. The narratives, symbols, and meanings that result can then be used to solve social problems, build networks, and enhance community action. These effects may be enhanced when art activities are integrated into the sports program and when the commercial elements support the social dimension. There are two key elements for the creation of liminality at events (Green \& Chalip, 1998; Handelman, 1998; Kemp, 1999; Lewis \& Dowsey-Magog, 1993). The first is a sense of celebration: the event is an occasion to rejoice. The second is a sense of social camaraderie: the celebrations are to be appreciated and possibly shared. Chalip (2006) suggests some strategies that could be used to foster a sense of celebration and camaraderie:

- Provide facilities and services ${ }^{3}$ to encourage and facilitate moments of informal socialization inside and outside of the venue (Melnick, 1993). Socialization around the venue may also include people who do not participate in the main event. The opportunity to socialize is not limited to the formal scheduled events. The simple fact of creating a celebration can be enough to encourage social interaction, facilitating informal social moments (e.g., "Third Half” Villages in Rugby).

- Create social events. García (2001) argues that art events can be useful additions to sports events because they can diversify the target of a sports event and give a greater sense of celebration.

- Make themed events. The use of symbols, colors, and decorations at events provides a visual statement that something special is happening. The theme is not limited to simple decorations, but tells stories and provides a sense of joy (Chalip, 1992).

3 Including litter bins, toilets, picnic benches, info points, food, vendors of soft drinks, and rules that allow early arrival and late departure to parking lots and surrounding spaces. 
Techniques for promoting celebration and socialization are closely related to economic techniques. Increasing the expenses of participants (Chalip, 2004) can determinate the risk of commercializing the event, with the consequential loss of the sense of communitas. Liminality and communitas make events fun and give the entertainment social value. Cultivating celebration and camaraderie can enrich the social life of the communities.

\section{From hospitality to sports tourism}

The philosophy of hospitality in ancient Greece formed the basis of the Olympic peace system and was the fundamental prerequisite for the celebration of agón. The practice of the agón (in Greek, $\dot{\alpha} \gamma \dot{\omega} v$ means "contest" or "competition") was a public event consisting of competitions and games organized on the occasion of religious celebrations in the sanctuary-town. The ancient Olympic Games were held in spaces and places consecrated for hospitality or xénia, a Greek word that means "gifts." Foreigners from every part of Greece met in Olympia to celebrate the agón. In this sacred place, a stranger or a foreigner, probably a former enemy, became a friend because he was both a guest and a host (hospes in Latin) in the sanctuary-town which belonged to the gods and to all of the Greeks, who recognized themselves in its spirit. In Greece, the ethics of the Olympic Games, was based on hospitality. Olympia was then the common home of all Greeks, the place where ethics was carried out, put into practice, and concretely exercised (Isidori \& Echazarreta, 2013). Nowadays, sports events are established around the world as a growing and vibrant sector of the industries of tourism and leisure and are believed to have considerable economic, socio-cultural, and political effects on the destination and on the groups that host them. In recent years, the concept of sports tourism has become widespread both in academic research and as a popular tourist product. ${ }^{4}$ The flow of sports tourism is growing and changing. More and more people, some for health reasons, some for pleasure or passion, choose their holiday in accordance with the sports supply, and sports have become a way to get to know the tourist destination. With the aim of developing the marketing of the region through the appeal of sports and culture,

4 The study of tourism related to sports events (Getz, 2008) was born in the 1990s and has been developing since 2000. In 1993, the Journal of Sport and Tourism was founded (after seven years in electronic format) as the Journal of Sport Tourism, edited by Joseph Kurtzman, as an initiative of the new Sport Tourism International Council. Gibson (1998) provided the first assessment of research on sports tourism and Weed (2006) reviewed the literature from 2000 to 2004 many cultural and sports events has been organized to attract a large presence of fans, athletes, and their families (Martelli, 2010). ${ }^{5}$ Charles Pigeassou (1997) believes that we can talk about sports tourism only when the displacement, destination, and modality of stay are chosen to participate (actively or passively) in the sports culture phenomena as an expression of physical activity practice and/or of cultural events (exhibitions, conferences, sports events), and not if this reason is ancillary and replaceable. There are different types of sports tourism: competitive, recreational, eventoriented, celebrity, nostalgia etc. (cfr. Ciampicacigli \& Maresca, 2004; Gammon \& Robinson, 2003; Gibson, 1998; Standeven \& De Knop, 1999;). ${ }^{6}$ It is possible to identify different categories of participants organized by motivations and modalities of participation in the table presented below (Table3).

Table 3. Typologies of sports tourism (figure adapted from the above-mentioned scholarly sources)

\begin{tabular}{|c|c|c|c|}
\hline & & \multicolumn{2}{|c|}{ MODALITIES } \\
\hline & & ACTIVE & PASSIVE \\
\hline \multirow{2}{*}{ 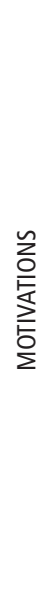 } & $\begin{array}{l}\text { FOR } \\
\text { WORK }\end{array}$ & $\begin{array}{l}\text { Professionals (Athletes): } \\
\text { - Competitive } \\
\text { - Training } \\
\text { - Education } \\
\text { - Entertainment } \\
\text { - Nostalgia } \\
\text { - Celebrity }\end{array}$ & $\begin{array}{l}\text { Professionals (Staff): } \\
\text { - Competitive } \\
\text { - Training } \\
\text { - Education } \\
\text { - Entertainment } \\
\text { - Nostalgia } \\
\text { - Celebrity }\end{array}$ \\
\hline & $\begin{array}{l}\text { FOR } \\
\text { LEISURE }\end{array}$ & $\begin{array}{l}\text { Amateurs (Athletes): } \\
\text { - Competitive } \\
\text { - Training } \\
\text { - Education } \\
\text { - Entertainment } \\
\text { - Nostalgia } \\
\text { - Celebrity }\end{array}$ & $\begin{array}{l}\text { Amateurs (Family/Friends): } \\
\text { - Competitive } \\
\text { - Training } \\
\text { - Education } \\
\text { - Entertainment } \\
\text { - Nostalgia } \\
\text { - Celebrity }\end{array}$ \\
\hline
\end{tabular}

These new "Xenos" (foreigners) can creatively find many different meanings in participating in these postmodern sports events. It is important from an ethical

5 There are many studies, both theoretical and empirical, on the theme of sports tourism, and in each of them the theme of sports events has a prominent place (see Gammon \& Kurtzman, 2002; Gibson, 2005; Higham, 2005; Hinch \& Higham, 2003; Hudson, 2002; Ritchie \& Adair, 2004; Standeven \& De Knop, 1999; Turco, Riley, \& Swart, 2002; Weed \& Bull, 2004). 6 1) Gammon \& Robinsom (2003) distinguish sports tourism into Hard Sports Tourism (competitive) and Soft Sports Tourism (recreational). 2) Gibson (2005) instead argues that sports tourism consists of leisure activities that require travel and which are based on participation (act, watch, commemorate). He identified three types of sports tourism: Sports Tourism Event, Celebrity and Nostalgia Tourism, and Active Tourism. 3) Standeven \& De Knop (1999) define sports tourism as "All forms of active or passive involvement in sports activities, carried out random or in an organized way for commercial or non-commercial reason, which require you to leave your home or your work office." 
point of view to understand the impact that sports and tourism can generate on the surroundings so that they can be managed more effectively in order to ensure the long-term viability of the sector (Fyall \& Jago, 2009). The logic of sustainable tourism is developed through the guarantee of the economic, social, and cultural well-being of the community (Richards \& Hall, 2000). While the event itself has a limited duration, the implications related to it can go beyond the event, both in the preparation phase and in long-term consequences. These long-term consequences refer to the legacy that the event leaves in a given context, such as from the point of view of an urban and territorial or economic, cultural, and territorial transformation (infrastructure, buildings, mobility systems) (Cherubini \& Mei, 2007). The concept of sustainability refers primarily to the environmental dimension and also includes the social and economic dimension (triple sustainability). The idea of "sustainable development" was first widely articulated in the Brundtland Report (World Commission on Environment and Development) of the United Nations in 1987. The Brundtland definition of sustainable development was framed as a development that meets the needs of the present without compromising the ability of future generations to meet their own needs. It posits that the only truly sustainable form of progress is that which simultaneously addresses the interlinked aspects of economy, environment, and social well-being. ${ }^{7}$ In these terms, a sustainable event is one that has been designed, organized, and implemented in a way that minimizes potential negative impacts and leaves a beneficial legacy for the host community and all who were involved. ${ }^{8}$

\section{From religiosity to serious leisure}

The atmosphere and attitudes created by the religious sports festival generated the Olympics' association with peace. As Reid observes (2006), the Games' ability to promote an atmosphere of friendship and solidarity among otherwise diverse (and often warring) people may be their most remarkable (and perhaps unexpected) legacy. The athletic contests at Olympia were primarily intended for the religious purpose of attracting pilgrims and (especially) the attention of the gods. According to the ancients Greeks, an Olympic victory was imagined as a visit from the winged goddess Nike, who swooped down

7 World Commission on Environment and Development (1987). Our Common Future. Oxford: Oxford University Press.

8 Adapted from the Green Meeting Guide 2009 and based on the principles developed at the ICLEI Greening Events Symposium in Barcelona, Spain, in September 2004 from Olympus to briefly bless the mortal athlete with a divine crown of sacred olives. The effects of such gatherings transcended the religious, however, and apparently resulted in feelings of community and solidarity among those who gathered. Athletes were supported, rewarded, and rooted on by their particular city-states, but the overall emphasis at Olympia was on everyone's common Hellenicity. In postindustrial society, new economic assets, new forms of work, new values, new social subjects, and, above all, new spaces and ways of using leisure to attract the category of "serious tourists" have emerged (Stebbins 1982, 1996). These new things have allowed "serious tourists" to develop a "tourist career" (Getz \& Mc Connell, 2011), studying issues related to an event, seeking a high quality of service, and, above all, seeking the added value given by the relational capital that an event can offer by its staff and the host community. The public of today, which is basically more educated (thanks to access to new media that allow for the easy exploration of topics of interest), richer, and have more free time, seeks more attractive cultural spaces. In these spaces, people are also looking for aesthetic pleasure and the satisfaction of a strong recreational and relational activity, and therefore have the need to be part of a community of common interests. The studies by Ryan (2002) and Urry (2000) have outlined a trend in international tourism demand towards the growth of the experiential tourist, multi-motivated and multi-sensorial, also called the post-mass tourist. The "serious leisure" (Stebbins, 1982, 1996) sought in the postindustrial society expresses a different attention towards tradition, cultural heritage, the local community, and the authenticity of relationships. For this reason sports events can provide different sociocultural moments that can answer to these needs. This situation is possible especially in the few cases in which local stakeholders adhere to the bottom-up development theory given by sustainable tourism and develop a new hybridization of knowledge among local administrators, event organizers, and experiential tourists with a postmodern lifestyle (García, 2001). In the current knowledge society, consumption is the main instrument for existential investment as well as for the construction and affirmation of our own identity. Participation in a cultural event can be an excuse to share collective rituals and feel part of a group or "social tribe" (Maffesoli, 2004). These events become gatherings, experiences to share and communicate value systems and lifestyles. However, in the case of postmodern cultural tourism, doing one thing at a time is no longer acceptable. The postmodern tourist wants the beach in the morning, gastronomy at noon, 
a conference or exhibition in the afternoon, and a concert in the evening. In addition, there is the pleasure of finding a hospitable community, a nice place, an extraordinary atmosphere, and the freedom to choose (Maussier, 2010).

\section{Conclusion: Ethics in the strategic planning of sports events}

The winning ethics of an event originates from the attitude of listening to the community of reference and its values and identity; it can remain a unique and unrepeatable event or become part of a larger project, which, as a whole, is a program that touches the foundations of a community, reaching tourism models focused on creating events (Maussier, 2010). Each type of sports event can establish different objectives for promoting a sport: focusing on social values, engaging multiple actors, fostering relationships, stimulating integration and dialogue between different cultures, keeping traditions alive, promoting the uniqueness of the host territory, affirming the administrative capacities of those who govern, and making a profit (Gravina \& Esposito, 2011). In the 'experience economy' however, tourist satisfaction comes first of all from a relationship with the local community. The quality of tourism depends not only on the system of reception, but above all on the quality of the territory, defined as the integration of resources, equipment, and intangible assets. The sports event, intended as a potential generator of tourist movements, can be conceived as a product of the tourist supply of a territory, becoming in effect a 'tourist resource' and 'pull factor' of the tourist destination, which chooses one or more 'demand segments'. It is important to clarify the concept of a destination in relation to tourism sports events. A territory in itself is not a tourist destination. The tourist destination is a combination of natural and/or cultural resources that have sufficient attraction ability to induce a traveler to make the necessary efforts to reach the destination with the necessary facilities for a stay (Ejarque, 2003).The organization of a sport event may be a useful territorial, urban and tourism marketing tool, as it can contribute to increasing the number of tourists and visitors to some locations, enhance the image and promote the notoriety of those locations, represent important leisure activities, attract investment and financing, and create significant economic effects (Costa, 2005, 2008; Ferrari, 2002). Types of sports events can be classified according to various parameters (Hall, 1992) such as frequency, number of active and passive participants, and media cover- age. There are events organized in different places at annual or longer intervals (the Olympics, world championships, etc.), events organized in a limited number of places that take place several times a year (sports championships in various disciplines), and events organized regularly in specific and determined places (in these cases, the place becomes the location for that specific event and is connected in an intrinsic mode). Among the most frequent types of sports events are competitive events, amateur events, events oriented towards recruitment, scholastic events, promotional events, mixed events, and special events (Cherubini \& Iasevoli, 2005). It is clear that with the periodicity or continuity of an event comes a different relationship with the host territory. To maximize the benefits, it is important that the strategic planning of the event is processed in relation to the sustainable development of the territory that it occupies. To promote a sports event or a place that makes the sport its main tourist attraction, a promotion strategy requires a thorough understanding of the actual needs of potential investors and careful evaluation of the local potential ( $g e-$ nius loci), as well as an examination of the compatibility between business strategy and local development, to ensure satisfaction both outside the community (visitors) and among local residents (De Angelis, 2005). Thus, it is necessary to apply real strategic planning development for the "EVENT" inside the development project of the tourist destination (Maussier, 2010). This process may be coordinated by the event manager as a facilitator of collaborative processes of development between the various stakeholders: residents, tourists, athletes, the media, sports organizations, actors of the destination, travel agencies, and sponsors (Getz \& Fairley, 2004). Starting from the analysis of the internal and external contexts, it is possible to define the initial situation using tools such as SWOT analysis, focus groups, predictive research, analysis of the territory, and benchmarking with a competitive scenario. This highlights a sustainable vision of strategic development to implement the various steps of the 'project event' through the careful definition of empirical models and work plans, establishing 'who does what,' assigning responsibilities, setting deadlines, and keeping costs under control in a systemic and territorial approach (Maussier, 2010). In this process, the first step is related to the study in aiming to understand the effects that tourism may have on the territory's economic, environmental, and social dimensions in order to achieve greater involvement and support from the local population. The second step consists of the study of the destination in terms of tourism in order to assess its resources and services. Subsequently, a tourism 
development plan should be developed for the destination in terms of the sustainability of the territory. Once evaluated, this plan must be presented to the citizens in order to make them feel involved and encourage them to participate in the tourism initiatives of the territory. Finally, it is necessary to position the territory in the minds of tourists in order to make it feel like a real destination. In this case, the event becomes an integral part of the tourism supply of the territory and can be compared to the travel motivations of tourists, a complementary element of, or primary motivation, for a holiday. It is necessary to think from a systemic perspective, considering local businesses, residents, and tourists. This requires the establishment of a collaborative logic and trust between the actors where the services are supplied (Betta \& Maccagnan, 2010; Di Tamma, 2002). The main difficulty that has been reported is the fact that the tourist product, in which we find the product of the sports event, is a multiple product, and is provided by a huge number of actors, including the residents, who are not easily controlled. Often, some of them do not even realize the feedback that their behavior has on the tourism product and the development of the social, economic, and cultural di- mensions of the destination (Ejarque, 2003). The relation between the event and the territory will be strategically important. The community dimension and the new social and ethical function that sports events can develop are the most interesting aspects that emerge from this reflection. These dimensions, if planned and programmed from the beginning, can become a 'pull factor' for serious sports tourists (Getz\& Mc Connell, 2011) and can generate new opportunities for a new ethical social change (Maussier, 2016). In conclusion, a new postmodern sports festival has emerged with new meanings attributed in an elective and creative way by new cosmopolitan participants who are educated and media-literate. This festival has also become an instrument of revitalization for the host community's social capital towards its own ethics. From the perspective of sustainable development, the festival can bring economic, environmental, and social benefits to both visitors and residential communities. It is suggested that future research might find interest in evaluating the ethical criteria used in some of the best practices of sustainable events to create ethical standards that should be followed in the different aspects of event management.

\section{REFERENCES}

Andersson, T.D., Rustad, A., \& Solberg, H. A. (2004). Local residents' monetary evaluation of sports events. Managing Leisure, 9, 145-158. Apolito, P. (1994), "Festa" in Enciclopedia delle Scienze Sociali, vol. IV, Istituto della enciclopedia italiana Treccani, Roma.

Arcodia, C., \& Whitford, M. (2008): Festival attendance and the development of social capital. Journal of Convention \& Event Tourism, 8(2), 1-18.

Aris, S. (1990). Sportbiz: Inside the sport business. London: Hutchinson.

Balduck, A.L., Maes, M., \& Buelens, M. (2011). The social impact of the Tour de France: Comparisons of residents. Pre- and post-event perceptions. European Sport Management Quarterly, 11(2), 91-113.

Bauman, Z. (2002). Modernità liquida. Bari: Editori Laterza.

Bell, D. (1973). The coming of post-industrial society: A venture in social forecastìng. New York: Basic Books.

Betta, G., \& Maccagnan, P. (a cura di) (2010). Le ricadute dei ritiri pre campionato della Juventus e di altre squadre in Trentino, Ricerche e approfondimenti, Report $n^{\circ} 32$, Osservatorito Provinciale per il turismo - Provincia autonoma di Trento. Disponibile in: http://www. turismo.provincia.tn.it/binary/pat turismo_new/report_ricerche/ Report_Juve.1277989836.pdf [06 giungo 2016].

Bramwell, B. (1997). Strategic planning before and after a mega-event. Tourism Management, 18, 167-176.

Brohm, J.M., (1976). Sociologie politique du sport. Paris: Jean-Pierre Delarge.

Burbank, M.J., Andranovich, G.D., \& Heying, C.H. (2001). Olympic dreams: The impact of megaevents on local politics. Boulder, CO: Lynne Rienner. Cambridge University Press.

Cardini, F. (1983). I giorni del sacro: Il libro delle feste. Novara: Editoriale Nuova.

Chalip, L. (1992). The construction and use of polysemic structures: Olympic lessons for sport marketing. Journal of Sport Management, 6, 87-98.

Chalip, L. (2006). Towards social leverage of sport events. Journal of Sport \& Tourism, 11(2), 109-127.

Chalip, L. (2004). Beyond impact: A general model for sport event leverage. In B.W. Ritchie \& D. Adair (Eds.), Sport tourism:
Interrelationships, impacts and issues (pp. 226-252). Clevedon: Channel View Publications.

Cherubini, S., \&Iasevoli, G. (2005). Il marketing per generare valore nel sistema evento. Ecole Supérieure de Commerce de Paris - EAP, 2122. Recuperado de http://www.marketing-trends-congress.com/ archives/2005/Materiali/Paper/It/Cherubini_Iasevoli.pdf

Cherubini, S., \& Mei, W. (2007). Marketing sportivo, territoriale, turístico. Roma: Nautica Editrice.

Ciampicacigli, R., \& Maresca, S. (2004). Due metalinguaggi si intrecciano: Sport e turismo. Milano: Ed. ISTEI, Istitutod'Economiad'Impresa, UniversitàdegliStudi di Milano- Bicocca.

Costa, N. (2005). I professionisti dello sviluppo turistico locale. Milano: Hoepli.

Costa, N. (2008). La città ospitale. Milano: Bruno Mondadori.

Crompton, J.L. (1999). The economic impact of sports tournaments and events. Parks and Recreation, 34(9), 142-150.

De Angelis, P. (2005). Marketing e turismo sportivo, Milano: Franco Angeli.

De Bres, K., \& Davis, J. (2001). Celebrating group and place identity: A case study of a new regional festival. Tourism Geographies, 3(3), 326337.

De Coubertin, P. (2000). Olympism: Selected writings. Lausanne: International Olympic Committee.

De Masi, D. (1985). L'avvento post-industriale. Milano: Franco Angeli.

De Masi, D. (2002). Ozio creativo. Milano: Rizzoli.

De Masi, D. (2015). Tag. Milano: Rizzoli.

Deccio, C., \& Baloglu, S. (2002). Non host community resident reactions to the 2002 Winter Olympics: The spillover impacts. Journal of Travel Research, 41, 46-56.

Delamere, T.A., Wankel, L. M., \& Hinch, T.D. (2001). Development of a scale to measure residents. Attitudes toward the social impacts of community festivals, Part 1: Item generation and purification of the measure. Event Management, 7(1), 11-24.

Di Tamma, M. (2002). Destination management: Gestire prodotti e sistemi locali di offerta. Torino: Giappichelli. 
Dumazedier, J. (1978). Sociologia del tempo libero. Milano: Franco Angeli. Dunning, E., Murphy, P., \& Williams, J. (1988). The roots of football hooliganism: An historical and sociological study. London New York: Routledge \& Kegan Paul.

Durkheim, É. (1963). Les formes élémentaires de la vie religieuse: Le systèmetotémique en Australie, Paris 1912 (tr. it.: Le forme elementaridella vita religiosa. Milano: Edizioni di Comunitá.

Ejarque, J. (2003). La destinazione turistica di successo. Milano: Hoepli.

Elias, N. (1988). Il processo di civilizzazione. Bologna: Il Mulino.

Elling, A., De Knop, P., \&Knoppers, A., (2001). The integrating and differentiating significance of sport. In J. Steenberger, P. De Knop, \& A. Elling (Eds.), Values and norms in sport. critical reflections on the position and meaning of sport in society. Oxford: Meyer \& Meyer Sport, p. 73-94, 374 p.

Ferrari, S. (2002). Event Marketing: I grandi eventi e gli eventi speciali come strumenti di marketing. Padova: CEDAM.

Fredline, L., Jago, L., \& Deery, M. (2003). The development of a generic scale to measure the social impact of events. Event Management, 8, 23-37.

Fredline, L., Raybould, M., Jago, L., \& Deery, M. (July, 2005). Triple bottom line event evaluation: A proposed framework for holistic event evaluation. Trabajo presentado en Third International Event Conference, The Impacts of Events: Triple Bottom Line Evaluation and Event Legacies. UTS, Sydney, Australia.

Fredline, E., \&Faulkner, B. (2001). Variations in residents' reactions to major motorsport events: Why residents perceive the impacts of events differently. Event Management, 7, 115-125.

Fyall, A.,\&Jago, L. (2009). Sustainability in sport \& tourism. Journal of Sport \& Tourism, 14(2-3), 77-81.

Gammon, S., \& Kurtzman, J. (2002). Sport tourism: Principles and practice. Eastbourne: Leisure Studies Association Publications.

Gammon, S.,\&Robinson, T. (2003). Sport and tourism: A conceptual framework. Journal of Sport Tourism, 8(1), 21-26.

García-Ferrando, M. (2006), Posmodernidad y Deporte: Entre la individualización y la masificación. Encuesta sobre hábitos deportivos de los españoles 2005. Madrid: Centro de Investigaciones Sociológicas.

García, B. (2001). Enhancing sports marketing through cultural and arts programmes: Lessons from the Sydney 2000 Olympic arts festivals. Sport Management Review, 4, 193-220.

Getz, D. (2002). Event studies and event management: On becoming an academic discipline. Journal of Hospitality and Tourism Management, 9(1), 12-23.

Getz, D. (2003). Sport event tourism: Planning, development, and marketing. In S. Hudson (Ed.), Sport and adventure tourism (pp. 4988). New York: Haworth.

Getz, D., \& Fairley, S., (2004). Media management at sport events for destination promotion: Case studies and concepts. Event Management, $8,127-139$.

Getz, D., (2008). Event tourism: Definition, evolution, and research. Tourism Management, 29(3), 403-428.

Getz, D., \& Mc Connell, A. (2011). Serious sport tourism and event travel careers. Journal of Sport Management, 25, 326-338.

Gibson, H. J. (1998). Active sport tourism: Who participates? Leisure Studies, 17, 155-170.

Gibson, H. J. (1998). Sport tourism: A critical analysis of research. Sport Management Review, 1, 45-76.

Gibson, H. (2005). Sport tourism: Concepts and theories. An introduction. Sport in Society, 8(2), 133-141.

Gravina, G., \& Esposito, G. (2011). La gestione degli eventi sportivi. Teramo: Dispense Università degli Studi di Teramo.

Green, B.C., \& Chalip, L. (1998). Sport tourism as the celebration of subculture. Annals of Tourism Research, 25, 275-291.

Gursoy, D., \& Kendall, K. (2006). Hosting mega events: Modelling locals' support. Annals of Toursim Research, 33(3), 603-623.

Guttmann, A. (1978). From ritual to record. New York: Columbia University Press.

Hall, M., (1992). Hallmark tourist events, impacts, management and planning. London: Belhaven Press.

Hall, C. (1992). Adventure, sport and health tourism, pp. 141-158 in B. Weiler and C.M. Hall (eds.), Special Interest Tourism. London: Belhaven.

Hall, C. M., \& Hodges, J. (1996). The party's great, but what about the hangover? The housing and social impacts of mega-events with special reference to the 2000 Sydney Olympics. Festival Management and Event Tourism, 4(1-2), 13-20.
Handelman, D. (1998). Models and mirrors: Towards an anthropology of public events. New York: Berghahn Books.

Heinemann, K., \& Puig, N (1996). Lo sport verso il 2000. Trasformazione dei modelli sportivi nelle società sviluppate. Sport \& Loisir, 1, 3-11.

Higham, J. (2005). Sport tourism destinations: Issues, opportunities and analysis. Oxford: Elsevier.

Hinch, T., \& Higham, J. (2003). Sport tourism development. Toronto: Channel View.

Hudson, S. (2002). Sport and adventure tourism. New York: Haworth.

Huizinga, J. (1983). Home ludens. Milano:Il saggiatore.

Isidori, E., (2012). Filosofia dell'educazione sportiva. Roma: Nuova Cultura.

Isidori, E., \& Echazarreta, R. R. (2013). Sport and philosophy of hospitality: Three questions on how to rethink contemporary sport education in light of gift and peace. Physical Culture and Sport. Studies and Research, 59(1), 5-10.

Kemp, S. F. (1999). Sled dog racing: the celebration of cooperation in a competitive sport. Ethnology, 38, 81-95.

Kim, H. J., Gursoy, D., \& Lee, S. B. (2006). The impact of the 2002 World Cup on South Korea: Comparisons of pre- and post- Games. Tourism Management, 27, 86-96.

Kim, K., \& Uysal, M. (2003). Perceived socio-economic impacts of festivals and events among organizers. Journal of Hospitality and Leisure Marketing, 10, 159-171.

Knop, P., (1988). Sport tourism: A state of the art. European Journal for Sport Management, 5(2), 5-20.

Lafargue, P., (1971). Le droit à la paresse, Paris 1883.Milano: Feltrinelli.

Lash, S., \& Urry, J. (1994). Economies of signs and space. London: Sage, London.

Lewis, J. L., \& Dowsey-Magog, P. (1993). The maleny 'fire event': Rehearsals toward neo-liminality. The Australian Journal of Anthropology, 4(3), 198-219.

Lipovetsky, G., (1995). L'era del vuoto. Saggi sull'individualismo contem poráneo. Milano: Luni

Lombardo, A. (2000). Pierre de Coubertin, Saggio storico sulle Olimpiadi moderne 1880-1914. Roma: RaiEri.

Lyotard, J. L., (1981). La condizione post-moderna. Rapporto sul sapere. Milano:Feltrinelli.

Maffesoli, M., (2004). Il tempo delletribù. Il declino dell'individualismonelle societàpostmoderne. Milano: Guerini e Associati.

Martelli, S. (2010). Lo sport mediato. Milano: Franco Angeli.

Marx, K. (1964).Il Capitale. Critica dell'Economia Politica, Libro Terzo. Roma: EditoriRiuniti.

Maussier, B. (2010.). Festival management e destinazione turística. Milano: Hoepli.

Maussier, B. (2014). Convergenza tra Feste Religiose e Festival di Approfondimento Culturale. In Boccia Artieri G., Borrelli D. (cur.), Il senso dei tempi. Per una sociologia del presente. Forum Ais Giovani (pp.69-84),Milano:Egea.

Maussier, B. (2016), Socio-Pedagogia degli eventi sportivi: Teoria e Prospettive Applicative, Rivista Italiana di Pedagogia dello Sport, 1, 4147, DOI:10.5281

McKercher, B., Mei, W. S., \& Tse, T. S. (2006). Are short duration cultural festivals tourist attractions? Journal of Sustainable Tourism, 14(1), 55-66.

Melnick, M.J. (1993). Searching for sociability in the stands: A theory of sports spectating. Journal of Sport Management, 7, 44-60.

Miller, S.G. (2004). Ancient Greek Athletics. New Haven: Yale University Press.

Mules, T., \& Faulkner, B. (1996).An economic perspective on special events. Tourism Economics, 2, 314-329.

Pigeassou, C. (1997). Sport and tourism: The emergence of sport into the offer of tourism. Between passion and reason: An overview of the French situation and perspectives. Journal of Sport Tourism, 4(2), 24-47. Porro, N. (2007). Lineamenti di sociologiadello sport.Roma: Carocci.

Portes, A. (1998). Social capital: Its origins and applications in modern sociology. Annual Review of Sociology, 24(1), 1-24.

Reid, L.H. (2006). Olympic sport and its lessons for peace. Journal of the Philosophy of Sport, 33, 205-214.

Richards, G., De Brito, M. P., \& Wilks, L. (2013). Exploring the social impacts of events. Australia: Routledge Advances in Event Research Series.

Richards, G., \& Hall D. (2000). Tourism and sustainable community development. London: Routledge.

Ritchie, B., \& Adair, D. (2004). Sport tourism: Interrelationships, impacts and issues. Clevedon: Channel View. 
Ritchie, J.R. B. (2000). Turning 16 days into 16 years through Olympic legacies. Event Management, 6, 155-165.

Roche, M. (2000).Mega-events and modernity: Olympics and expos in the growth of global culture. London: Routledge.

Rowe, D. (1999). Sport, culture and media. The Unholy Trinity. London: Open University Press.

Russell, B., (2012). L'elogiodell'ozio. Milano: Tea.

Ryan, C. (2002). The tourist experience. London: Continuum.

Standeven, J., \& De Knop, P. (1999). Sport tourism. Champaign: Human Kinetics.

Stebbins, R. A. (1982). Serious leisure: A conceptual statement. The Pacific Sociological Review, 25(2), 251-272.

Stebbins, R. A. (1996). Cultural tourism as serious leisure. Annals of Tourism Research, 23(4), 948-950.

Sugden, J., \& Tomlinson, A., (2001). Power games: A critical sociology of sport. New York: Routledge.

Thompson, E.P. (1969). Rivoluzione industriale e classe operaia in inghilterra. Milano: Il Saggiatore.

Tomlinson, A., \& Young, C. (2006). National identity and global sports events. Culture, politics, and spectacle in the Olympics and the Football World Cup. Albany: State University of New York Press.
Touraine, A., (1970): La società post-industriale. Bologna: Il Mulino.

Turco, D., Riley, R., \& Swart, K. (2002). Sport tourism. Morgantown: Fitness Information Technology Inc.

Turner, V. (1969). The ritual process: Structure and antistructure. New York: Cornell University Press, Ithaca.

Turner, V. (1974). Liminal to liminoid, in play, flow and ritual: An essay in comparative symbology. In E. Norbeck (Ed.), The Anthropological Study of Human Play (pp. 53-92). Pennsylvania: Rice University Studies.

Turner, V. (1982).Celebration: Studies in festivity and ritual. Washington: Smithsonian Institution Press.

Urry, J. (2000). Lo sguardo del turista. Il tempo e ilviaggionella società contemporanea. Roma: Edizioni Seam.

Weed, M. (2006). Sports tourism research 2000-2004: A systematic review of knowledge and a meta-evaluation of methods. Journal of Sport and Tourism, 11(1), 5-30.

Weed, M., \& Bull, C. (2004). Sports tourism: Participants, policy and providers. Oxford: Elsevier.

Wilks, L. (2011). Bridging and bonding: Social capital at music festivals. Journal of Policy Research in Tourism, Leisure and Events, 3(3), 281-297. 